\title{
Adapting to climate change: Perceptions of maple producers in New York and Vermont
}

\author{
Diane Kuehn a * \\ State University of New York College of Environmental Science and Forestry \\ Lisa Chase ${ }^{b}$ \\ University of Vermont Extension \\ Vermont Tourism Research Center \\ Thomas Sharkey c \\ State University of New York College of Environmental Science and Forestry
}

\begin{abstract}
Submitted April 26, 2017 / Revised June 27, 2017 / Accepted June 27, 2017 / Published online September 8, 2017

Citation: Kuehn, D., Chase, L., \& Sharkey, T. (2017). Adapting to climate change: Perceptions of maple producers in New York and Vermont. Journal of Agriculture, Food Systems, and Community

Development, 7(3), 43-65. http://dx.doi.org/10.5304/jafscd.2017.073.020
\end{abstract}

Copyright (C) 2017 by New Leaf Associates, Inc.

\author{
Abstract \\ Maple production is an important part of local \\ food systems in the Northeastern U.S. and Canada, \\ where producers rely on maple as a source of \\ a * Corresponding author: Diane Kuehn, Associate Professor, \\ Department of Forest and Natural Resources Management, \\ State University of New York College of Environmental \\ Science and Forestry; 1 Forestry Drive, 320 Bray Hall; \\ Syracuse, NY 13210 USA; +1-315-470-6561; \\ dmkuehn@esf.edu \\ ${ }^{\mathrm{b}}$ Lisa Chase, University of Vermont Extension, Vermont \\ Tourism Research Center \\ c Thomas Sharkey, Department of Forest and Natural \\ Resources Management, State University of New York College \\ of Environmental Science and Forestry

\section{Disclosure} \\ This project was supported by the Northeastern States \\ Research Cooperative (NSRC) through funding made available \\ by the USDA Forest Service under project number 132623. \\ The conclusions and opinions in this paper are those of the \\ authors and not of the NSRC, the Forest Service, or the \\ USDA.
}

income and as the basis for longstanding family and community traditions. Like many other sectors of the food system, maple production is vulnerable to climate change because of its potential impacts on forest type, tree health and vigor, and timing of sap flow. Since maple producers depend on the health of sugar maples for their livelihood and cultural traditions, adapting to changes in maple production will likely be necessary in the future and will require planning. The goal of this study is to assess the perceptions of maple producers and engage them in the development of strategies for adapting to the potential impacts of climate

\section{Authors' Notes}

Basic results of the interviews for this study have been presented at the Northeastern Recreation Research Symposium (see Sharkey, Kuehn, \& Chase, 2015). Most of the interview information presented herein has not been previously presented.

Results from this study have also been made available through an online ESF report (see Kuehn, Chase, Sharkey, \& Powers, 2016). 
change. The mixed methods research approach for this study included interviews and a survey of maple producers in the Northern Forest region of New York and Vermont. Results indicate that more than half of the maple producers who responded to the survey expressed concerns about climate change, and more than two-thirds had already made or were planning to make modifications to their businesses. Two factors that were identified as most important to respondents when assessing adaptability to climate change are resiliency of the maple producers' sugar bush and the producers' ability to adopt new technologies. These findings are not just relevant for maple production; they have important implications for climate change adaptation of food systems.

\section{Keywords}

Adaptability; Climate Change; Demographics; Business Characteristics; Maple Production

\section{Introduction}

Maple production is an important part of local food systems in the Northeastern United States and Canada, where it is a longstanding cultural tradition as well as a source of income for familybased businesses. Vermont and New York are the two highest maple-producing states in the U.S. (U.S. Department of Agriculture, National Agriculture Statistics Service [USDA NASS], 2017). The Northern Forest (NF) region of these states (Figure 1) is home to over 1,000 commercial maple production operations, primarily small businesses that depend on maple products (e.g., maple syrup and sugar) as a source of revenue. Many of these businesses have been in operation for decades (even generations), and there is substantial potential to expand maple production in several states in the Northeast and Midwest in the future (Farrell \& Chabot, 2012).
Climate change is expected to impact the entire food system (Miller et al., 2013), and maple production is no exception. Predictions of climate change impacts regarding levels of sap production from maple trees vary, with some models suggesting that the season will be shorter in the Northeastern U.S., and others that the season will start significantly earlier (Skinner, DeGaetano, \& Chabot, 2010). Skinner et al. indicate that the number of days on which sap flows from maples will not change through 2100; however, maple production business owners will need to collect sap earlier in the season to "maximize the number of sapflow days" (2010, p. 685). Climate data for the northeast indicate that the sugaring season has shortened by about $10 \%$ over the past 40 years (Global Warming Mountaintop “Summit,” 2007). Changes in precipitation and temperature are forecasted to create shifts in forest type from sugar maple to oak-hickory-pine in the next 50 to 100 years (Global Warming Mountaintop "Summit," 2007). Maples stressed by climate change may be more susceptible to invasive pests and diseases, further reducing their vigor (Wilmot, 2012).

Because maple producers depend on the health of sugar maples for their economic well-being and as the foundation of family and community traditions, adapting to and planning for changes in maple production will likely be necessary in the

\section{Figure 1. Northern Forest Region of NY and Vermont}

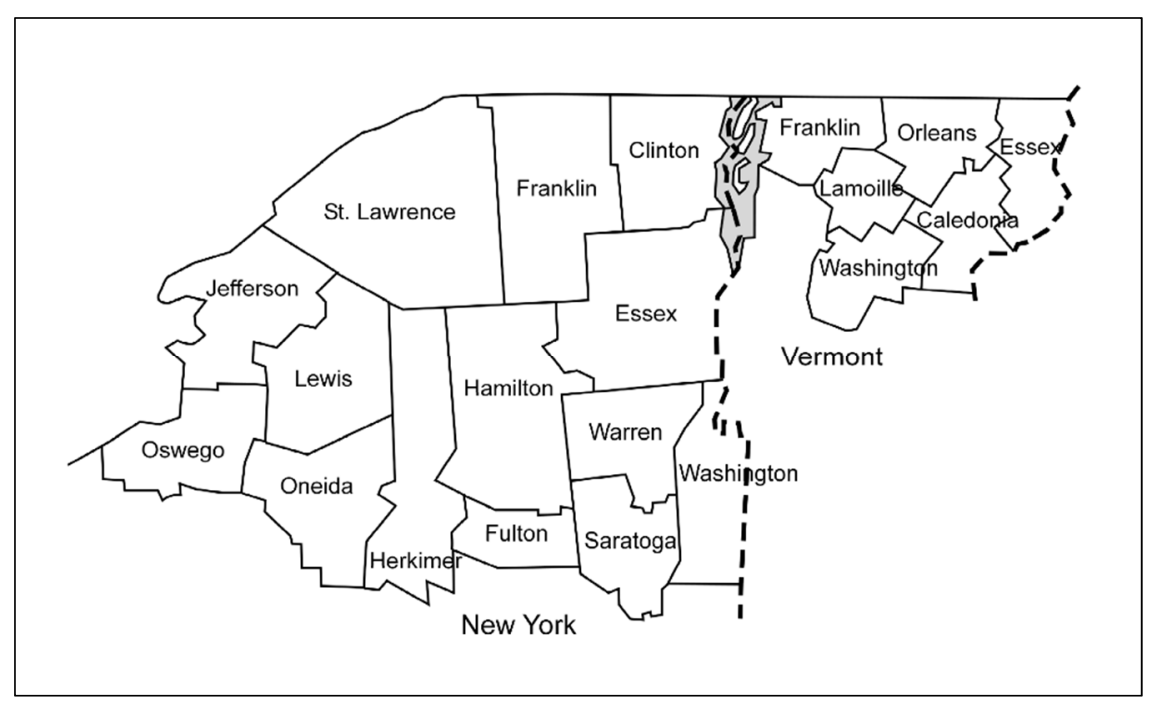

Map based on a Northern Forest and Counties Map by Conservation Advisory Services, 1994. 
future. Past research indicates that understanding the factors, including perceptions of climate change, that affect the ability of producers to adapt to change is essential (Jemison, Hall, Welcomer, \& Haskell, 2014; Ogalleh, Vogl, \& Hauser, 2013). A range of views exist on climate change in the United States, from those who believe action must be taken to reduce carbon emissions, to those who do not believe climate change is occurring. Ten percent of the general public does not believe the climate is changing and is opposed to actions that address climate change through adaptation or mitigation (Chase \& Grubinger, 2014; Leiserowitz, Maibach, Roser-Renouf, \& Hmielowski, 2012). A survey of farmers in Iowa found similar results: 5\% of the respondents did not believe in climate change and did not wish to address climate change (Arbuckle, 2011). To date, no studies have assessed maple producers' beliefs about climate change, their ability to adapt to change, or the mechanisms in place within their families, communities, and industry to plan for change. This study seeks to provide a better understanding of these beliefs for maple producers in the Northern Forest Region of New York and Vermont.

The goal of this study is to identify strategies that help maple producers plan for and adapt to the potential impacts from climate change. In order to accomplish this goal, the objective is to identify the elements influencing the ability of businesses to adapt to climate change. We hypothesize that there will be significant relationships among business characteristics, demographics, perceptions concerning climate change, and producers' perceptions of their ability to adapt to climate change; we use a path analysis to identify significant relationships. While this research focuses on maple production, the methods and results have broad implications for other sectors of agriculture and food systems.

\section{Literature Review}

Adaptability is a business's ability to respond technologically to change, to be flexible in terms of its customer base (i.e., its market focus), and to have a management structure that can respond to change (Tuominen, Rajala, \& Möller, 2004). According to Walker and Ruekert (1987), a high degree of adaptability in a business is essential since firms unable to adapt and innovate often fail. Resiliency (i.e., "the capacity of a system to absorb disturbance and reorganize while retaining essentially the same function" [Folke, Carpenter, Walker, Scheffer, Chapin, \& Rockström, 2010, p. 3]) is important to business adaptability since it can determine how quickly businesses "bounce back" from catastrophic events such as severe weather. Research on small-business resilience during an economic downturn suggests that firms with high levels of adaptability and flexibility are more likely to be successful (Smallbone, Deakins, Battisti, \& Kitching, 2012). For maple producers, resourcebase resiliency (i.e., how quickly a maple forest or "sugar bush" can recover from catastrophic events) and flexibility in management and customer base are likely crucial to the long-term success of the business.

Adapting to the changing climate is a challenge for small businesses, particularly those as important to the traditions and economy of the Northern Forest Region as maple producers. Previous studies have used "adaptability scales" to measure (on a five-point scale) business owners' perceptions of their businesses' level of adaptability (Lansberg \& Astrachan, 1994; Tuominen et al., 2004). This study uses this type of scale to study maple producers' perceptions concerning adaptability to climate change. Four components of adaptability are considered: customer base, management, technology, and resource base.

In addition to the components of adaptability, an understanding is needed of demographic, business, and social system (i.e., connections between individual businesses and family, community, and industry) characteristics. Previous studies have shown that the owners of small, family-based businesses, such as maple production businesses, need more than basic management and marketing skills to be successful. Eberle, Milliman, Peterson, and Rendleman (2004) found (for the dairy industry) that understanding family and community relationships is critical for successful transitions in times of uncertainty. Davis and Stearn (1981) emphasize the importance of being able to differentiate between business operations and family dynamics, since the two are often closely integrated in family-based businesses. Björnberg 
and Nicholson (2007) found that family businesses are dependent upon the ability of the family running the business to work effectively together and to adapt to change.

Because of the importance of family dynamics to business success, it is essential that these elements also be considered for maple producers. In addition, business success has been linked to managers' knowledge and perceptions of new technologies, demographics (education and age), business characteristics (e.g., firm size [Peltier, Zhao, \& Schibrowsky, 2012]), business-related experience (Richbell, Watts, \& Wardle, 2006), and the existence of a written business plan (Rue \& Ibrahim, 1998). In order to provide a comprehensive understanding of business adaptability, this study integrates these elements as well as measures of adaptability in its theoretical framework (Figure 2).

\section{Applied Research Methods}

This study was composed of two components: interviews with a sample of maple producers, and a survey of all identified maple producers in the Northern Forest region of New York and Vermont (Figure 1). Information from online sources (e.g., New York State Maple Producers Association (NYSMPA), the Vermont Maple Sugar Makers Association (VMSMA), and business websites) and from the University of Vermont Extension program was used to create a contact list for all known maple producers in the Northern Forest Region of New York and Vermont.

Fourteen telephone interviews were conducted with 15 maple producers in the Northern Forest region of New York and Vermont in 2014 and 2015 (one interview was conducted with two business partners). The list of key contacts was used to randomly select producers for interviews. Interviews were scheduled by sending out e-mail requests. Interviews were recorded (with interviewee permission) with an Olympus DS-5000 digital voice recorder and transcribed using Dragon

Figure 2. Business Adaptability Model Related to the Potential Impacts of Climate Change (CC) on Maple Production Businesses

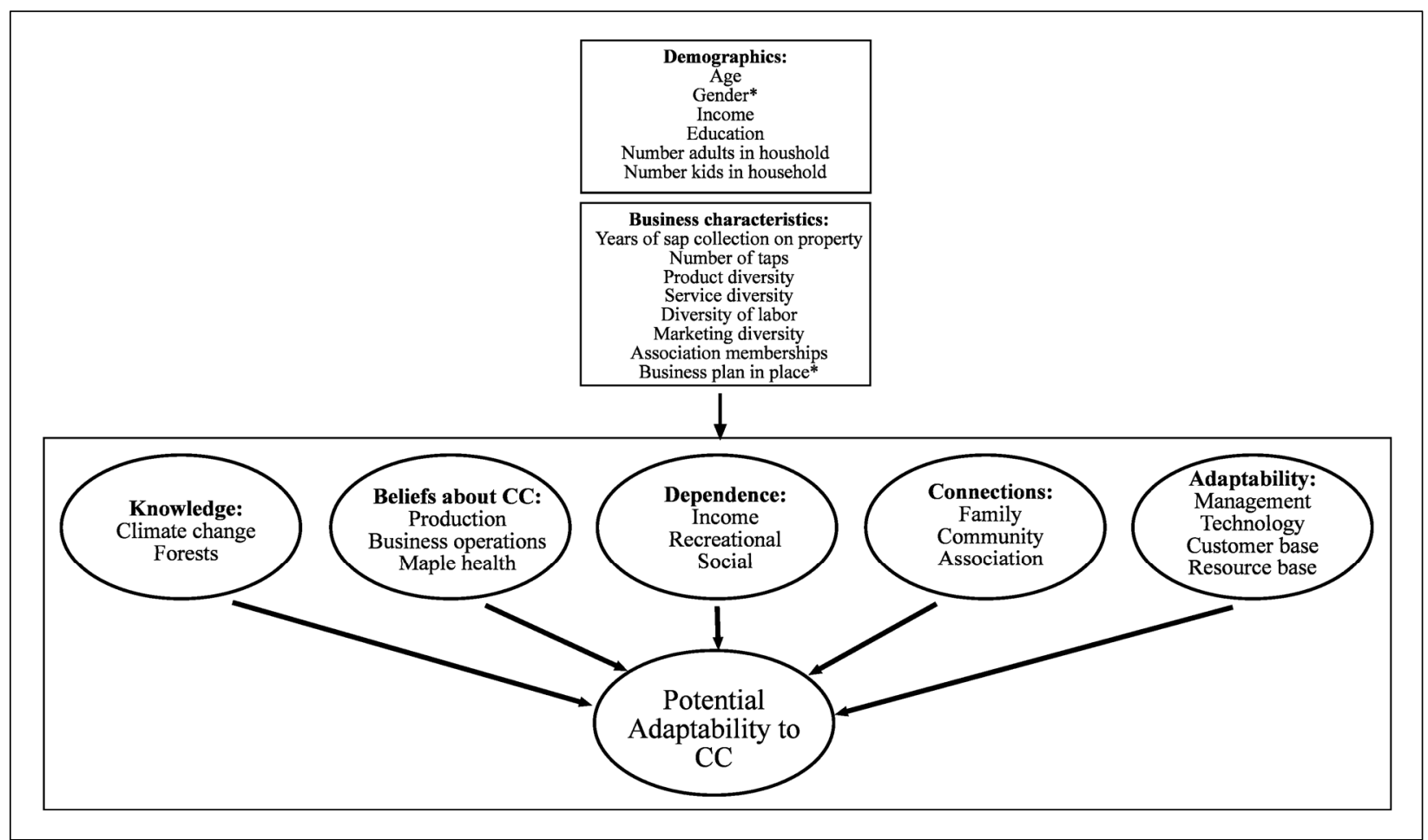

Note: An asterisk indicates that the item was not included in the final analysis.

Source: Kuehn, Chase, Sharkey, \& Powers, 2016. 
Dictate 4.0 software (Nuance Communications, 2014). Interviews ranged in length from 16 to 45 minutes.

The interview guide included questions about maple producers' perceptions of climate change, the characteristics and structure of their businesses, their businesses' products and services, the use of up-to-date technology, and the adaptability (i.e., resiliency) of their sugar bush. Interview questions related to adaptability, dependence, and connections (Table 1) were identified from Bélanger, Vanasse, Parent, Allard, \& Pellerin (2015); Björnberg and Nicholson (2007); Eberle et al. (2004); Peltier et al. (2012); Tuominen et al. (2004); and Walker and Brown (2004). Questions regarding business characteristics and maple production were derived from an interview guide provided by Dr. Brenda Murphy of Wilfred Laurier University, Ontario, Canada. The interviews were structured so that the most contentious subjects (i.e., perceptions of climate change and how maple producers deal with change) were addressed only after rapport had been built between the interviewer and interviewee. Comments expressed by interviewees were transcribed verbatim. These transcriptions were then used to identify concepts relevant to interviewees' perceptions of climate change and the elements influencing their business' ability to adapt to change (Figure 2).

Interview data were analyzed by the first and third authors for reoccurring concepts related to the themes identified through literature review (Table 1). In addition, grounded theory techniques (Creswell, 2009) were used to identify themes previously unidentified for business owners' perceptions of climate change (e.g., beliefs concerning climate change, knowledge of climate change and of forests, and adaptability of the resource base (i.e., sugar bush resiliency; see Table 1). We identified the number of respondents indicating each concept within each theme. Intercoder agreement (i.e., cross-checking concepts identified by two different researchers [Creswell, 2009]) was calculated for each concept using ReCal online software (http://dfreelon.org/utils/recalfront/) (Freelon, 2010). An intercoder agreement percentage of $80 \%$ is usually considered an adequate indication of consistency of the data (Miles \& Huberman, 1994); however, since the closest percentage to $80 \%$ that could be obtained mathematically based on the number of interviews in this study was $79 \%$, this percentage was considered an adequate indication of intercoder agreement.

The themes confirmed and/or identified through analysis of the interview data were used to write a questionnaire for the mail and online survey (Table 1). The questionnaire included questions related to the characteristics of respondents' businesses; respondents' demographic characteristics; their knowledge of climate change and northeastern forests; their beliefs related climate change; their dependence on their business for economic, recreational, and social reasons; the connection of their business to family, community, and the maple production industry; perceived adaptability of their business with regard to management, technology, customer base, and resource base (i.e., sugar bush resiliency); and potential adaptability to climate change (Figure 2). Questions were in multiple choice, fill-in-the-blank, and five-point scale formats. For questions related to the perceptions of maple producers, the questionnaire used a scale ranging from -2 (strongly disagree) to 0 (neutral) to 2 (strongly agree). Lists of services and marketing and promotion techniques were also included on the questionnaire. "Diversity of services provided" was calculated as the sum of all services identified on the questionnaire; "diversity of marketing" was calculated as the sum of all marketing and/or promotion techniques implemented by the respondent.

The survey was conducted by mail and online in the fall of 2015 using a modified tailored design method (Dillman, 2007). We distributed four mailings of the questionnaire to the 1,322 maple producers identified in the Northern Forest Region of New York and Vermont via first-class mail. The first and third mailings contained a cover letter, full questionnaire, and postage-paid return envelope; the second and fourth mailings were reminder postcards. An identical online version of the questionnaire was provided using SurveyMonkey (San Mateo, CA) for those respondents who prefer submitting responses via the Internet. A link for the online survey was included in the questionnaire mailings; respondents were required to enter a 
number from the back of their mailed questionnaire to participate in the online version.

Following completion of the full survey, a short, one-page survey was mailed to all of the maple producers who did not respond to the full survey. Comparisons were made between the respondents to the full and to the short surveys to identify any significant differences $(p \leq 0.05)$ in a few important variables. Finding a significant difference between the two groups could indicate that the population of maple producers is somehow different than the group of individuals who responded to the full survey.

Data were entered into PASW Statistics version 18.0 (SPSS, Inc.). Following data entry, a confirmatory factor analysis was conducted using EQS 6.1 software (Bentler, 2010) to confirm the arrangement of variables into factors (Hair, Anderson, Tatham, \& Black, 1998). Because some variables were written on the survey "in the negative" or opposite of how other variable statements were written, these variables were reverse coded before the factor analysis was conducted. The variable means for the reverse-coded questions shown in the tables in Appendices A and B do not show the reverse coding (i.e., the means of the actual responses are included in each table); however, the factor means shown in these tables were calculated using the reverse-coded data. For the confirmatory factor analyses, a root mean square error of approximation (RMSEA) of less than 0.05 (Byrne, 2006, p. 100) and a comparative fit index (CFI) of "close to 0.95" (Byrne, 2006, p. 97) were used to identify adequate fit of the variables into factors. The reliability of factors was checked by calculating the Cronbach's alpha. Alphas above 0.7 are considered to have good consistency and can be used for statistical analyses such as path analysis (Hair et al., 1998). Following these tests, the responses for the questions composing each factor were averaged together for each respondent, creating the summated scales used in the path analysis (Hair et al., 1998). The summated scales for all respondents were then averaged to identify the overall factor means for all respondents reported in tables in Appendices A through D.

A path analysis was used to identify significant relationships $(p \leq 0.05)$ among the factors (the relationships tested are indicated with arrows in Figure 2). Variables related to demographics (e.g., age, years of education) and business characteristics (e.g., number of taps or holes put in the trees to extract the sap) were also included. The path analysis utilized robust methods as suggested by Byrne (2006); good fit was attained when the CFI was near 0.95 , the RMSEA was less than 0.05 , and the Satorra-Bentler chi square reached a $p$-value of greater than 0.05 (Byrne, 2006).

\section{Results}

\section{Interviews}

Fourteen in-depth telephone interviews were conducted with maple producers after obtaining interviewee permission. Eight interviews were with New York producers and six were with Vermont producers; one interview included both owners of the business. Seventy-two percent of the interviewees thought climate change was occurring; two respondents indicated that climate change has been accelerated by humans, two had no clear idea about climate change, and one considered it to be a political and marketing ploy (Sharkey, Kuehn, \& Chase, 2015).

Themes related to business management and climate change were identified from previous literature and from the interviews. "Knowledge of climate change" and "knowledge of forests in the northeast" were two of the constructs identified from interview results (Table 1). Knowledge of climate change was indicated by interviewees' comments concerning the "slow global warming of the world" (indicated by 36\% of respondents; intercoder reliability $(\mathrm{ICR})=93 \%$ ), "extreme or odd weather patterns" ( $50 \%$; ICR $=86 \%)$, and "warmer weather, less snow, early spring” ( $29 \%$; ICR $=86 \%)$.

Interviewee \#8 (male, in business 5 years): "The ocean temperatures are changing, and the ocean temperatures and the currents are actually what dictates weather patterns everywhere else. So as the ice caps melt, the water gets warmer, which is what creates the wind, and the wind actually dictates how the whole atmosphere revolves and conducts itself. So yes, the climate is changing." 
Journal of Agriculture, Food Systems, and Community Development

ISSN: 2152-0801 online

http://www.foodsystemsjournal.org

Table 1. Themes Used to Write the Mail and Online Survey

\begin{tabular}{|c|c|}
\hline Themes & Source \\
\hline Knowledge of climate change & Interview results \\
\hline Knowledge of forests & Interview results \\
\hline Beliefs about impacts of climate change on production & Interview results \\
\hline Beliefs about impacts of climate change on business operations & Interview results \\
\hline Beliefs about impacts of climate change on maple health & Interview results \\
\hline Dependence on maple production for income & Walker \& Brown, 2004; Interview results \\
\hline Dependence on maple production for recreational purposes & Interview results \\
\hline Dependence on maple production for social purposes & $\begin{array}{l}\text { Bélanger et al., 2015; Walker \& Brown, 2004; } \\
\text { Interview results }\end{array}$ \\
\hline Connections of business to family & Eberle et al., 2004; Interview results \\
\hline Connections of business to community & Eberle et al., 2004; Interview results \\
\hline Connections of business to industry & Eberle et al., 2004; Interview results \\
\hline Adaptability of business in management & $\begin{array}{l}\text { Björnberg \& Nicholson, 2007; Tuominen, et al., 2004; } \\
\text { Interview results }\end{array}$ \\
\hline Adaptability of business in technology & $\begin{array}{l}\text { Peltier, Zhao, \& Schibrowsky, 2012; Tuominen, et al., } \\
\text { 2004; Interview results }\end{array}$ \\
\hline Adaptability of business in customer base & Tuominen, et al., 2004; Interview results \\
\hline Adaptability of resource base (i.e., sugar bush resiliency) & Interview results \\
\hline Ability of business to adapt to climate change & Interview results \\
\hline
\end{tabular}

Knowledge of forests was indicated by interviewees discussing the potential reduction of maples in forests in the southern portion of the sugar maple range $(21 \%$ of interviewees; ICR = $93 \%$ ), as well as the observation that maples on north-facing slopes might do better as temperatures increase $(14 \%$; ICR $=86 \%)$.

Interviewee \#14 (male, in business 10 years): "I think that some producers may see an effect if they have a southerly aspect slope on their sugar bush. But if they have a northerly aspect slope, like I do, it may take longer for those effects to impact their business."

Three belief-related themes concerning climate change were identified from the interviews: production, business operations, and maple health. Fifty percent of interviewees indicated beliefs concerning production by indicating that there would be an impact on production levels in the future due to climate change (ICR $=86 \%$ ); $57 \%$ believed that this impact would not occur in their lifetime $(\mathrm{ICR}=86 \%)$.

Interviewee \#14 (male, in business 25 years): "Looking forward 100 years, if the temperatures are steadily increasing, we will see declines in maple syrup production."

Beliefs concerning business operations were mainly related to changes made to operations such as tapping trees earlier ( $43 \%$ of interviewees; ICR $=$ $79 \%)$ and being flexible about when tapping begins $(21 \% ; \mathrm{ICR}=79 \%)$.

Interviewee \#13 (male, in business 4 years): "The big things are in terms of when to tap the trees....When the season begins to how the sap is flowing. I think that's being affected by changing temperatures in the climate." 
Beliefs concerning maple health were indicated by comments about the future health and vigor of maple trees due to potential impacts from climate change. Thirty-six percent of interviewees discussed changes they thought would occur in maple forests due to climate change. Five $(36 \%)$ indicated that maples would no longer be able to thrive due to the warmer weather conditions ( $\mathrm{ICR}=79 \%$ ).

Interviewee \#1 (male, in business 1 year): "If it gets hotter and drier it will affect species that can't adjust to the extreme conditions. And I don't know enough about our species to know which ones will be affected most, but obviously maple is the one that is closest to home and the species that we will watch the most."

Four interviewees $(29 \%)$ indicated that the changing temperatures could encourage the spread of invasive species and tree diseases $(\mathrm{ICR}=86 \%)$.

Interviewee \#13 (male, in business 4 years): "As for the health of the maple trees, I do worry about changing temperatures and how that'll affect the winters here, and potentially new invasives that are going to affect my maple trees and new diseases."

Three themes were identified concerning the interviewees' "dependence" on their business for financial, recreational, and social purposes. All interviewees indicated that they use their syrup within their family and to give to friends (ICR= $100 \%$ ); $79 \%$ use their maple business as a supplemental source of income (ICR=79\%).

Interviewee \#2 (male, in business 17 years): "It's a nice additional source of income. It helps us pay our taxes, and also gives us a bit of spending money."

"Recreational dependence" was indicated when interviewees mentioned that they liked being outdoors ( $21 \%$ of interviewees; ICR $=93 \%$ ), the physical exercise involved with being out in their maple forest or "sugar bush" ( $29 \%$; ICR $=86 \%)$, that maple production was a hobby for them $(36 \%$;
ICR $=79 \%$ ), and/or that they "love" or enjoy making syrup $(43 \%$; ICR $=79 \%)$.

Interview \#10 (male, in business 4 years): "It's a healthy activity to produce it, and we enjoy it because of that. I think that's the simplest answer."

"Social dependence" was shown when interviewees discussed socializing with other business owners or with customers $(14 \%$; ICR $=100 \%)$, and that maple production was "in their blood" or an important part of their heritage $(36 \%$; ICR $=93 \%)$.

Interviewee \#8 (male, in business 5 years): "Well, of course you've got to make money, but I'm not really doing it for the money, because I'm never going to get rich doing this. I guess it's just one of those things that you have in your blood."

Three themes related to "connections" of the interviewee and his or her business to family, community, and the maple industry were identified in the literature and confirmed through the interviews. "Connections to family" were shown by the integration of family members into the production process. Seventy-nine percent of interviewees indicated that their spouse or significant other was either an employee or partner in their production business (ICR $=100 \%$ ); $21 \%$ indicated that their children or grandchildren help during sugaring season $(\mathrm{ICR}=86 \%)$. Five businesses $(41 \%$; ICR $=$ $86 \%)$ indicated that their business has been passed down through the generations.

"Connections to community" were identified by the interviewees' involvement in communitybased events, farmers markets, and open houses (64\% of interviewees; ICR $=93 \%$ ); $29 \%$ indicated that they did not have a strong connection to their community for business purposes ( $\mathrm{ICR}=100 \%$ ).

Interviewee \#4 (female, 20 years in business): "It's really made us be more active in the local community as a small business. We're part of the chamber of commerce and actively involved in the local community thanks in large part to our maple business." 
"Connections to the maple industry" were primarily shown by involvement in maple producers associations; $93 \%$ of interviewees indicated that they are members of a maple producers association $(\mathrm{ICR}=93 \%)$.

Interviewee \#9 (male, in business 30 years): "I do a lot of work with the state association working with government officials and things like that."

Interviewees felt that association involvement was important because it kept them up-to-date on the industry $(36 \%$; ICR $=86 \%)$, provided opportunities for networking with other producers at conferences and association meetings $(50 \%$; ICR $=$ $79 \%$ ), and provided important promotional tools $(36 \%$; ICR $=79 \%)$.

Three themes identified through literature review were confirmed through the interviews in relation to "adaptability" in management, technology, and customer base; a fourth theme, "adaptability of the resource base," was identified through analysis of the interview data (Table 1). "Adaptability in management" was shown through the flexibility of maple producers with regard to decision-making. Seventy-nine percent of the interviewees had businesses that were adaptable with regard to management because all decisionmaking was done either by themselves or in conjunction with their spouse $(\mathrm{ICR}=79 \%)$. Decisions were also made by $29 \%$ of interviewees based on input from professionals such as accountants, Cooperative Extension agents, and foresters (ICR $=93 \%$ ). The family-based system used by most producers seemed to provide further adaptability in that if an employee quit or was unavailable during sugaring season, family members or the owner would complete the needed tasks $(86 \%$; $\mathrm{ICR}=86 \%$ ).

Interviewee \#4 (male, lifelong involvement in business): "That actually did happen a few years back. My wife's father was really sick and she had to fly out to take care of him during production season. When that happened, my parents came to the farm and helped pick up some slack."
"Adaptability in technology" was expressed by interviewees when they discussed the adoption of new sugaring technology. Thirty-six percent of interviewees indicated that they have already installed new technologies to adapt to climate change (ICR=93\%), while $29 \%$ indicated that they plan to do so in the future (ICR=86\%). The majority of owners $(79 \%)$ indicated that the financial expenses associated with adopting new technologies influences their adoption to some degree (ICR $=79 \%$ ); 29\% indicated that they need to see a relatively quick return on investment to make the adoption of new technologies feasible (ICR $=86 \%)$. Only two interviewees indicated that nothing stops them from adopting new technologies; both were the owners of larger businesses with high profit margins $(\mathrm{ICR}=100 \%)$.

Interviewee \#4 (male, lifelong involvement in business): "It's really all about the numbers and how fast it will get a return on our investment. So we just sit down with a calculator and crunch the numbers. If we think we can make our money back say, in five years, then we might move forward with buying new equipment or something like that."

"Adaptability in customer base" was related to the diversity of visitor markets served by interviewees, and the geographic breadth of the customer base. Thirty-six percent of interviewees served local customers only (i.e., customers within the immediate geographic region of the maple production business; ICR $=100 \%$ ); $57 \%$ served local customers as well as customers from elsewhere in the state and out-of-state $(\mathrm{ICR}=93 \%)$. Only one interviewee sold products via the Internet.

Finally, "adaptability of the resource base" was identified through the interviewees' perspectives on how they would react if severe damage to their sugar bush occurred due to a catastrophic event. Twenty-nine percent indicated that they would harvest timber if needed to generate income (ICR= 93\%), 21\% would replace sap lines as quickly as possible $(\mathrm{ICR}=79 \%)$, and $36 \%$ would buy sap from other producers $(\mathrm{ICR}=86 \%$ ). Many of the actions indicated by interviewees indicated the limited resiliency of the sugar bush itself. 
Interviewee \#2 (male, in business 17 years): "There was a bad windstorm back in '98, and it put us out of business for a year. We lost a lot of customers during that year, but we bought more sap and tried to keep as many customers as possible."

\section{Mail Survey}

\section{Response Rate}

The full survey was mailed to 1,322 businesses in the Northern Forest Region of Vermont and New York. Undeliverable addresses, deceased individuals, and noncommercial maple producers were removed from the contact list, leaving a qualified sample of 1,011 maple producers. Of this qualified sample, 269 maple producers returned a completed questionnaire for a response rate of $27 \%$. Of the usable questionnaires $(N=264), 86$ were completed by New York producers and 178 by Vermont producers (Kuehn et al., 2016).

A short survey was sent to the 742 individuals who did not respond to the full survey; 70 maple producers returned this short survey. Comparisons between responses to the full and short surveys revealed no significant differences $(p \leq 0.05)$ between full survey and short survey responses to questions concerning number of taps, willingness to make business changes, having the financial resources necessary to adopt new technologies, catering to diverse clientele, and having back-up strategies in place to deal with sugar bush (i.e., resource base) damage. The age and years of education of respondents were also compared; no significant differences were found, indicating that the respondents to the full survey are likely representative of maple producers in the Northern Forest region (Kuehn et al., 2016).

\section{Demographics}

The age of respondents ranged from 18 to 88 , and the average respondent was 61 years of age $(n=$ 261). The average respondent had 14.5 years of education (includes 12 years for high school; $n=$ 249). Most $(94 \%)$ were male $(n=261)$. Nearly half of the respondents had an annual household income between US\$26,000 and US\$75,999. Eighty-seven percent of respondent households were home to two or more adults; $19 \%$ of households had at least one child ( $n=261$; Kuehn et al., 2016).

\section{Business Characteristics}

Maple syrup had been produced on the land of respondents for an average of 82 years in NY and VT combined (an average of 51 years in NY and 97 years in Vermont; $n=256$ ). Producers in NY had an average of 2,576 taps in 2014, and had added an average of 681 taps between 2010 and $2014(n=86)$; Vermont producers averaged 4,876 taps, adding an average of 1,470 taps in the same five-year period $(n=175)$. The average producer made 1,337 gallons (5,062 liters) of syrup in $2014(n=248)$; the maximum amount produced by a single producer was 32,500 gallons (123,026 liters). Most respondents (91\%) did not have a written business plan in place, although $5 \%$ indicated that they were currently writing one ( $n=255$; Kuehn et al., 2016).

\section{Diversity in Products, Services, and Marketing and Promotions}

Although all the maple producers surveyed provide maple syrup, $36 \%$ of respondents provide other products as well. Maple cream, maple candy, and maple granulated sugar were the products most commonly mentioned by respondents. Eighty-one percent of respondents sell only maple products; $13 \%$ sell maple products plus one non-maple product, and $6 \%$ sell maple products plus two or more non-maple products $(n=258$; Kuehn et al., 2016).

Sixty-one percent of maple producers offer at least one type of service, the most common being tours of their maple production facility and/or sugar bush, an "open house" during Maple Weekend (state-sponsored events used to promote maple production businesses in both states), and programs for school groups. Twenty-four percent of respondents offer one type of service, $11 \%$ offer two different services, $15 \%$ offer three to four services, and $11 \%$ offer five or more services. The mean number of services offered by respondents was 1.6, with a median of $1.0(n=254$; Kuehn et al., 2016).

About one-quarter of businesses do not use any form of marketing or promotion; the 
remaining $74 \%$ of respondents use diverse promotional approaches, including word-of-mouth, a sign outside their business, business cards, listings on maple producers association websites, their own business website, and Facebook. Of those respondents who promote their business, $39 \%$ use only one form of promotion, $20 \%$ use two forms, $14 \%$ use three forms, and the remaining $27 \%$ use four or more forms. The mean number of promotional approaches implemented by respondents was 2.1, with a median of $1.0(n=256$; Kuehn et al., 2016).

\section{Factors Related to Perceptions of Climate Change}

\section{Knowledge of climate change and forests}

Respondents were asked to rate their knowledge of climate change and of forests in the northeast on a scale of -2 (strongly disagree) to 0 (neutral) to 2 (strongly agree). For "knowledge of climate change," the average respondent had a mean of 0.3 , indicating weak agreement with statements related to perceived knowledge of climate change (Appendix A). The mean for "knowledge of forests" was slightly higher $(M=0.43$; Kuehn et al., 2016).

\section{Beliefs concerning potential impacts from climate change} Three beliefs concerning the potential impacts of climate change on maple production, business operations, and maple tree health were examined. The first, "beliefs concerning impacts on production," had a negative and moderately strong mean ( $M=-0.62$; Appendix A), indicating that the average respondent believes that climate change may cause a reduction in sap production in the future. The second belief factor concerning impacts on business operations had a moderately strong and negative mean of -0.7 , indicating that respondents (on average) believe that maple producers may need to change how they operate in the future because of climate change. The third belief concerning impacts on maple health also had a strong, negative mean $(M=-0.9)$, suggesting that respondents (on average) believe that climate change will harm maple health in the future (Kuehn et al., 2016).
Dependence of maple producers on their business Three different factors were calculated concerning the dependence of maple producers on their business. The first, dependence on the income from maple production (i.e., "income dependence"), had a moderately weak mean of -0.46 (Appendix B). This result suggests that the average respondent likely has sources of income other than maple production. The second factor, "recreational dependence," had a moderately high mean of 1.0; the average respondent may rely on maple production for getting them outdoors and for physical exercise. The third factor, "social dependence," had a moderate mean of 0.46 ; the average respondent does appear to rely on maple production to a small extent for social reasons such as interacting with friends and family, attending social events, and carrying on cultural traditions. The mean for one variable included in this social dependence factor was high (i.e., "Maple production is important because it is part of my heritage and/or family traditions;" $M=0.87$ ), indicating a strong heritagebased connection between the average respondent and their production business (Kuehn et al., 2016).

\section{Connections of maple production businesses with family, community, and business associations}

Three factors were calculated concerning the connections of maple production businesses (Appendix $\mathrm{C}$ ). The first, "connections between business and family," had a mean of 0.4 , suggesting that the average respondent perceives a moderate connection between their business and family. The second factor, "connections of business with community," had a moderate and negative mean of -0.6; the average respondent does not appear to rely on their community for organizing events, networking opportunities, and promotions. The third factor, "connections between business and associations," focused on relationships between respondents and industry-based organizations such as maple producer associations. This factor had a moderate and positive mean $(M=0.4)$, indicating that the average maple producer has a moderate connection with his or her association for promotions and networking overall. However, the variable "I greatly depend on a maple producers association 
for up-to-date information about maple production" had a strong mean (0.85); this informationproviding aspect of associations appears to be important to the average producer (Kuehn et al., 2016).

\section{Business adaptability}

Four factors were related to business adaptability (Appendix D). "Adaptability of management" concerned the perceived willingness and ability of respondents and their employees to plan ahead and quickly make decisions. The mean for this factor was 0.81 , indicating that the average respondent had a strong and positive perception of their management adaptability. The second factor, "adaptability of technology," had a relatively weak mean of 0.23; the average respondent may not always have the finances and ability to keep up-to-date with new maple production technologies. The third factor, "adaptability of customer base," had a moderate mean of 0.40 . Although the clientele base of the average respondent is perceived as only moderately diverse with regard to selling to retail, individuals, and families $(M=0.47)$, respondents perceived the diversity of locations where customers reside (i.e., in-state and out-of-state) as high ( $M=0.84$; Kuehn et al., 2016). The fourth factor, "adaptability of the resource base," had a negative and moderate mean (-0.56), suggesting that the average maple producer does not have back-up options in place for periods of low production or catastrophic events affecting their sugar bush (Kuehn et al., 2016).

\section{Potential adaptability to climate change}

This factor focused on producers' perceptions of their business to potentially adapt to climate change in the future with regard to labor, technology, customer base, and resource base (i.e., sugar bush; Appendix D). The slightly negative mean $(M=-0.22)$ suggests that the average respondent does not perceive (at this time) that their business will be able to easily adapt to climate change. Adaptability of the resource base may be of particular concern to respondents since the average respondent most strongly disagreed $(M=-0.49)$ with the variable "If any severe damage to my sugar bush occurred due to climate change, my business could quickly change how it collects and/or obtains sap."

\section{Path Model}

A path analysis using robust techniques was conducted to identify the significant $(p \leq 0.05)$ relationships among the factors shown in the tables in Appendices A through D, as well as demographic and business characteristics (Figure 3). Prior to the path analysis, respondents missing data for any of the independent or dependent variables were removed from the database, leaving a sample of $n=170$. Thirty-seven separate models were run during the analysis; during each step in the process, factors and variables that were not significant were removed from the model.

In the first step of analysis (Figure 3), one factor (knowledge of forests) was identified as significantly related to perceptions of adaptability of business to climate change (i.e., dependent variable; $S-B_{X}{ }^{2}(1)=60.043, p<.001, \mathrm{CFI}=.337$, RMSEA =.591). In step two, relationships between belief-related factors and the dependent variable were added; only one belief factor was significant (i.e., beliefs concerning the impacts of climate change on production; $S-B_{X}{ }^{2}(6)=142.167, p<.001$, $\mathrm{CFI}=.162$, RMSEA =.366). In step three, factors related to the "dependence" of the producer on maple production for income, recreation, and social purposes were added. Both the income dependence and social dependence factors were identified as significant, and model fit improved $(S$ $B_{X}{ }^{2}(10)=18.627, p=0.045$, CFI $=.764$, RMSEA $=$ $.071)$. In step 4 , the factors related to "connections" of the business to family, community, and association were included; only connections with the community were found to be significant $\left(S-B_{X}{ }^{2}\right.$ $(21)=117.982, p<0.001, \mathrm{CFI}=.249$, RMSEA $=.165)$. In step 5, the "adaptability" factors were added (Figure 4). Although the factors of adaptability of management, technology, and resource base were found to be significant, several factors (income dependence, social dependence, and connections to community) were identified as no longer significant and were removed from the model $\left(S-B X^{2}\right.$ $(28)=148.621, p<0.001, \mathrm{CFI}=.519, \mathrm{RMSEA}=.160)$.

Demographic and experiential characteristics were tested for both direct relationships with the 
Figure 3. Step-by-Step Process Used to Conduct the Path Analysis

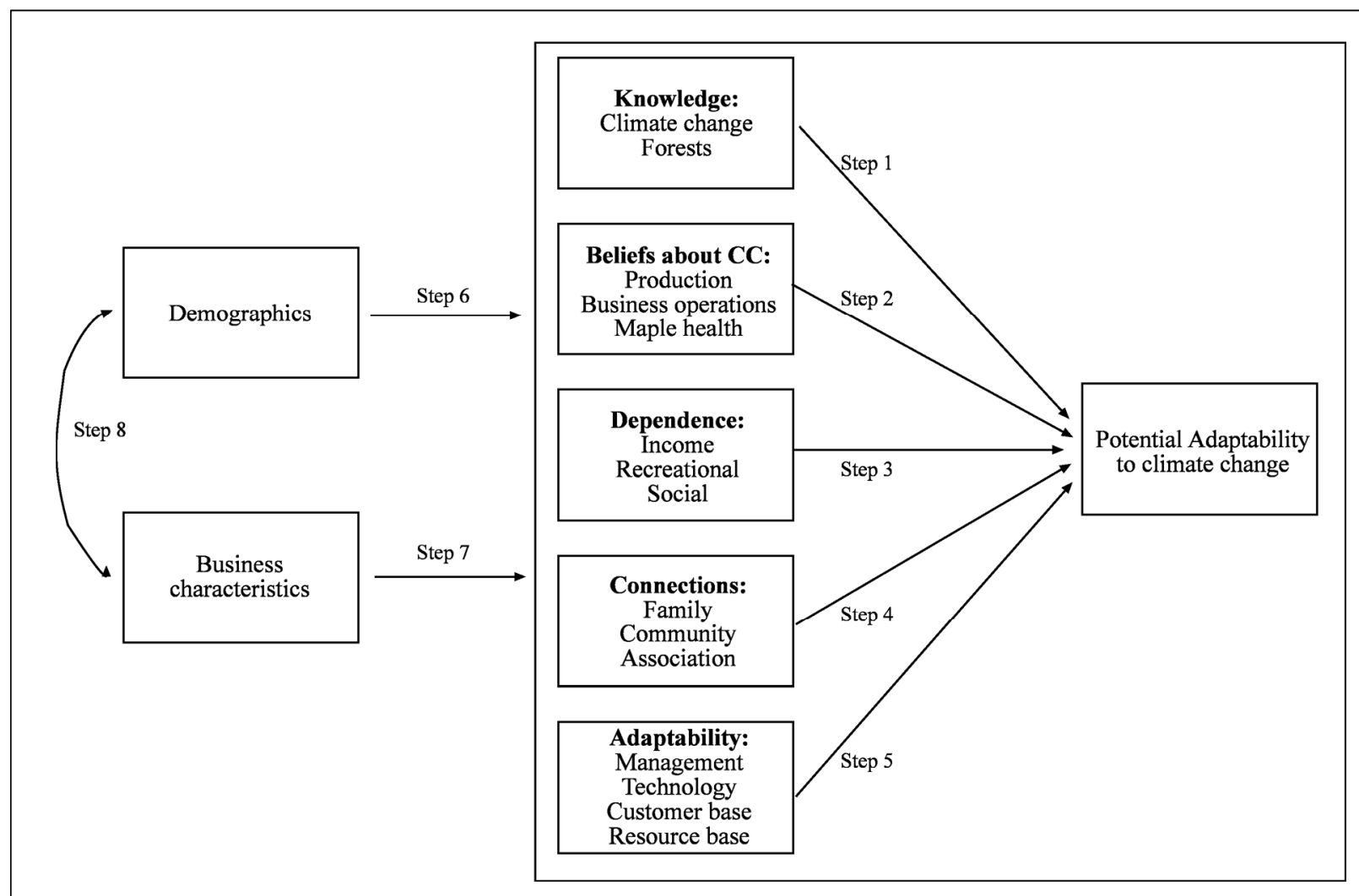

dependent variable and indirect relationships mediated by the significant factors identified in steps 1 through 5; none had significant direct relationships with perceived ability to adapt to climate change, but seven did have significant indirect relationships (i.e., education, number of children in household, diversity of services, age, income, number of taps, and diversity of marketing; $S-B_{X}{ }^{2}(61)=249.449$, $p<0.001$, CFI $=.555$, RMSEA $=.135$ ). Results of a LaGrange Multiplier test revealed potential relationships among the mediating factors; these relationships were added to the model $\left(S-B_{X}{ }^{2}\right.$ $(58)=196.380, p<0.001, \mathrm{CFI}=.673$, RMSEA $=.119)$. Relationships between exogenous variables were added in step 8; model fit improved significantly $\left(S-B X^{2}(54)=73.369, p=0.041, \mathrm{CFI}=.954\right.$, RMSEA =.0.046). Because the Satorra-Bentler chi square results were not yet showing adequate fit, additional analyses were run to test for improvement in model fit upon removal of each exogenous variable. Model fit was shown to improve when "income" was removed ( $\mathrm{S}-\mathrm{B}_{\mathrm{X}}{ }^{2}$ $(47)=58.676, p=.118, \mathrm{CFI}=.970, \mathrm{RMSEA}=.038)$. Although Wald test results indicated that no parameters needed to be dropped from the model, LaGrange multiplier test results indicated the existence of a significant relationship between beliefs concerning production and adaptability in technology. The addition of this relationship resulted in the final model (Figure 4; $S-B_{X}{ }^{2}$ $(46)=54.832, p=.174, \mathrm{CFI}=.977, \mathrm{RMSEA}=.034)$.

\section{Discussion}

This study employed a mixed-methods approach comprising interviews with maple producers and a mail/online survey to study the relationships affecting respondents' perceived adaptability to climate change in the maple production industry. The interviews revealed themes not previously identified in the literature, thus enabling a comprehensive examination of business adaptability for this specific industry, with general implications for 
Figure 4. Path Analysis Model

Standardized parameter estimates are given above one-way arrows; correlations are given near two-way arrows.

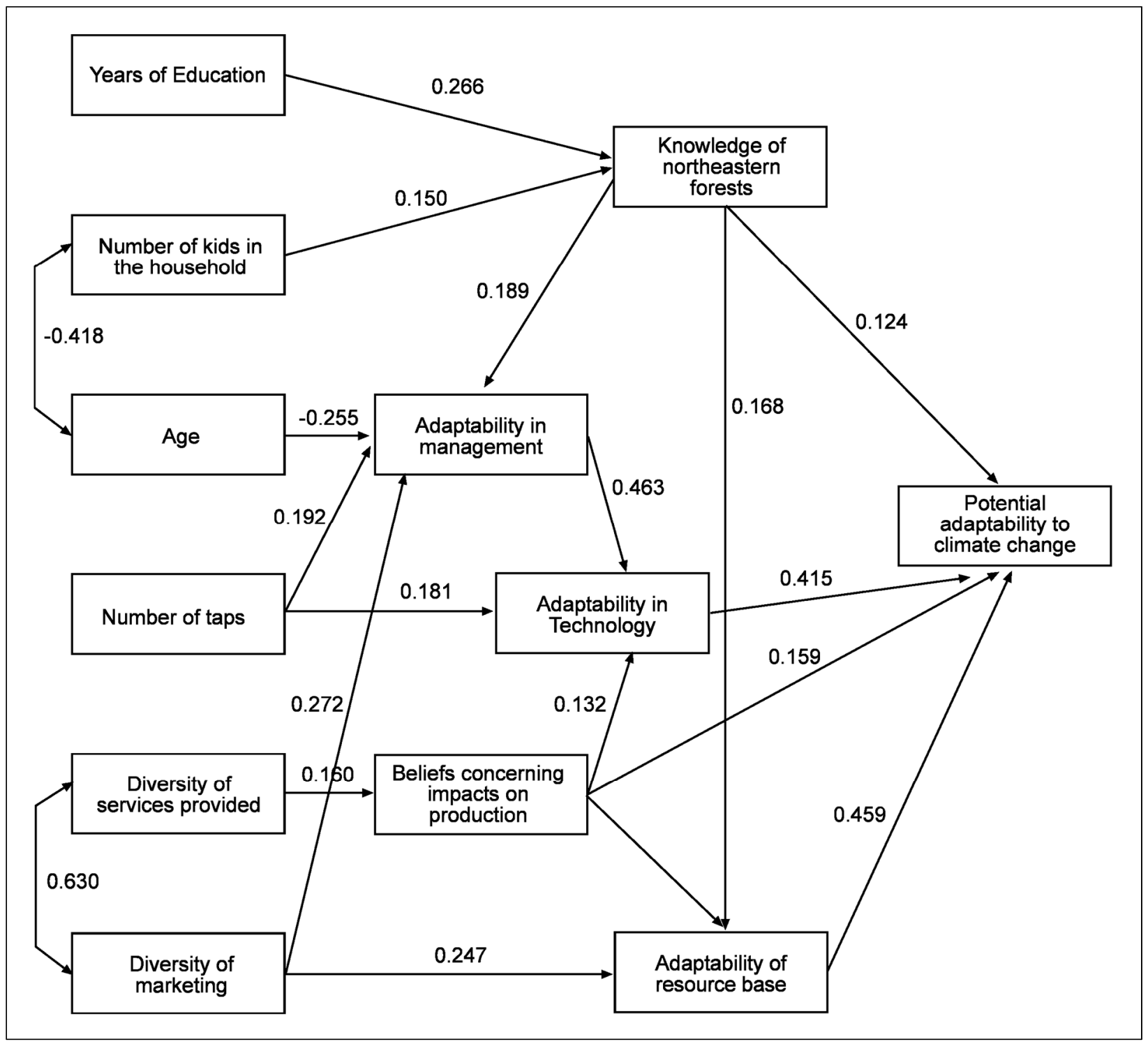

small business adaptability. Through path analysis, we were able to confirm that significant relationships in this new adaptability model do exist. Furthermore, the results provide some important concepts for maple producers and other small resource-based businesses to consider with regard to the potential impacts of climate change on their business and industry, and to other external factors that could affect productivity.

The four factors found to be directly associated with the dependent variable of "potential adaptability to climate change" are adaptability of the resource base (i.e., resiliency of the sugar bush), adaptability in technology, knowledge of northeastern forests, and beliefs concerning the impacts of climate change on production. Of these four factors, adaptability of the resource base and adaptability in technology had the strongest relationships (standardized parameter estimates $=0.459$ and 0.415 , respectively). Based on these results, it appears that the perceptions of respondents regarding the environmental and/or economic 
setting of their business can be particularly important in their perceptions of the future viability of their business. Furthermore, for some responding business owners, perceptions regarding the ability of their business to adapt to change may be greatly influenced by their ability to obtain new technologies. Although adaptability in technology has been identified as an important element influencing business success by previous researchers (Peltier, Zhao, \& Schibrowsky, 2012; Tuominen et al., 2004), adaptability of the resource base may be unique to resource-based businesses such as those involved in agriculture (Perks \& Medway, 2012), natural resources management, and the maple production industry. Similarly, knowledge of the northeastern forest and beliefs concerning maple production are specific to the maple industry; however, it is possible that knowledge and beliefs specific to the business environment of other types of businesses may affect business owner perceptions as well.

Several of these factors found to directly influence "potential adaptability to climate change" also served as mediating variables. Adaptability in technology appears to be one of the most important mediating variables in our model, as adaptability in management, beliefs concerning production, and number of taps are all directly related to it. Furthermore, number of taps also directly influences adaptability in management. These results suggest that larger businesses (i.e., those with a greater number of taps) may be able to more easily handle management problems and afford new technologies than smaller businesses, possibly because of greater profit margins.

Other significant variables in the path model include demographic characteristics, years of education, number of children in the household, and age. The relationship between years of education and knowledge of northeastern forests suggests that increased education levels could help maple producers better understand the environment in which their business operates. Knowledge of northeastern forests is also influenced by the number of children in the household, indicating that maple producers with children may be more involved in learning about forests in general, perhaps as a way of engaging their children in their maple production business. Age seems to influence adaptability in management; the older a respondent was, the less likely they were to perceive themselves as flexible in responding to management problems.

Diversity in services was found to influence production beliefs, while diversity in marketing and promotion influenced both adaptability in management and adaptability of the resource base.

Respondents who offer diverse services and implement diverse marketing and promotion strategies are more likely to perceive their sugar bush as resilient. These types of services may help maple producers maintain some level of income, even when production is low. Similarly, diverse marketing strategies may help maintain customer interest in a business, helping the maple producer weather periods of low production. It is important to note that "diversity of products" was not identified as a significant factor in the model, likely because $81 \%$ of respondents offer only maple products. It is possible that producers who do sell a diversity of maple and non-maple products are able to maintain a higher income during times of low maple production. Having a diverse product line may be particularly important in low production years since value-added maple products can be made using smaller amounts of syrup.

Several factors were not significant in the model; even though they were scored highly by respondents, these factors do not appear to influence respondents' perceptions of potential adaptability to climate change. First, "connections of business with family" was not significant, even though $92 \%$ of respondents receive assistance from family and friends during the tapping season. Furthermore, $18 \%$ of producers plan to pass their business on to their children, indicating that these family connections are important to respondents and could influence the future of the industry. The heritage and traditions involved in this industry appear to be especially important to respondents, with high averages for the variables "maple production is in my blood" and "maple production is important because it is part of my heritage and/or family traditions."

Next, "connection of business with associations" was not identified as a significant influence 
on potential adaptability to climate change, even though associations were identified by respondents as an important source of information. Associations are likely to remain important to maple producers in the future should impacts from climate change occur, primarily because they provide producers with up-to-date information on production technologies. In addition to associations, education programs such as the Cooperative Extension were another important source of up-todate information for respondents.

Finally, "dependence on maple production for recreational purposes" was not identified as significant in the model, but had the highest average $(M=1.00)$ of all factors, indicating that the recreational aspects of maple production are important to the average respondent. Similarly, the variable "maple production is important to me because of the enjoyment it provides" had the highest average $(M=1.41)$ of all variables included on the survey. Thus, although the recreational aspect of maple production is not likely to affect a business's potential adaptability to climate change, it is likely to affect whether a business owner decides to continue with maple production.

This study has important implications for research regarding the adaptability of food systems to climate change and other stressors. Although the model shown in Figure 4 was developed specifically for maple producers in the Northern Forest Region of New York and Vermont, the constructs identified through a mixed-methods process can be adapted for research on other types of businesses. For example, the concepts of "knowledge of climate change" and "knowledge of northeastern forests" should be considered for future research in a broader light as "knowledge of businessrelated stressors" and "knowledge of business setting." Similarly, "adaptability of the resource base," though focused in this study on sugar-bush resiliency, could very well be relevant to other businesses, especially those related to agriculture and natural resources. The constructs of "beliefs" related to business production and operations, though operationalized according to their relevance to climate change in this study, could be refocused on different issues important to business owners. Other constructs such as "dependence," "connections," and "adaptability" are all important to other businesses and should be considered for inclusion in future business adaptability models as well.

It is important to note the limitations of this study. First, the survey questions are designed to obtain the perceptions of respondents. As with any social science study, the perceptions of respondents may not always exactly reflect the situation as experienced by the respondent or as perceived by those not in the sample of respondents. Second, although efforts were made to obtain the most comprehensive list of maple producers in both New York and Vermont, producers who do not advertise on the Internet or who do not advertise online through an association may have not been included in the sample. Third, response bias is possible, as with any survey. Although the nonrespondent follow-up survey did not reveal differences between respondents and nonrespondents, both surveys used the term "climate change" and it is possible that some maple producers chose not to answer the survey for that reason. Fourth, only maple producers in the Northern Forest Region of New York and Vermont were included in this study; maple producers in more southerly regions, which are more likely to be affected sooner by climate change, were not included. Finally, the survey instrument did not specify a time horizon for impacts of climate change, leaving the interpretation open to respondents. Future research is needed to better understand maple producers' perceptions of adaptability to climate change over different time horizons.

\section{Conclusion}

This study sought to identify the elements facilitating and limiting the ability of maple production businesses to adapt to climate change. Specifically, the alternative hypothesis tested was that significant relationships exist among business characteristics, demographics, perceptions concerning climate change, and producers' perceptions of their ability to adapt to climate change. We found many significant relationships among the factors and variables studied, supporting the hypothesis. The two factors that seem most important to respondents when assessing adaptability to climate 
change are resilience of the resource base (the sugar bush in this case) and ability to adopt new technologies. Other factors such as beliefs concerning impacts on production, adaptability in management, knowledge of northeastern forests, and size of the business (as based on the number of taps) also appear to be important influences on respondents' perceptions of their potential ability to adapt to climate change in the future. Although this study is specific to maple producers, the basic concepts included in the model can be adapted to other business types and considered for inclusion in future research on food system adaptability to climate change. These constructs include knowledge, beliefs, connectedness, and adaptability; demographic and business characteristics should be taken into account as well.

In New York and Vermont, the findings of this study are currently being used to help maple producers identify strategies for adapting to climate change. Specific strategies, such as tapping earlier in the maple season, updating sap collection technologies by installing vacuum systems, and expanding the number of taps, are being implemented or considered for future implementation by the majority of respondents. Despite the uncertainty of the future, the results of the survey suggest that maple producers are committed to their operations, with only $10 \%$ planning to retire, sell, or close their business over the next five years. The vast majority of maple producers are optimistic about the future of maple production, with $48 \%$ wanting to increase their number of taps over the next five years, $42 \%$ wishing to keep their business "as is," and 18\% wanting to expand the services and products they offer. These committed maple producers are managing to adapt to changing conditions, and they are attempting to create the foundation for a resilient maple industry into the future. This study highlights how one sector of the food system is adapting to climate change, with broad implications for adaptability of other sectors of the food system also affected by climate change.

\section{Acknowledgements}

The authors wish to thank the many individuals who assisted with this project, including Helen Thomas and the New York State Maple Producers Association board of directors; Matt Gordon, Vermont Maple Sugar Makers Association; Tim Wilmot and George Cook, University of Vermont Extension; Stephen Childs and Michael Farrell, Cornell Cooperative Extension; Dr. Brenda Murphy, Wilfred Laurier University, Ontario, Canada; Joel Ramtahal, Justin Kindt, and Sarah Powers for their assistance with data entry; the anonymous reviewers of this article; the maple producers who volunteered their time for the interviews; and the many maple producers who completed the survey.

\section{References}

Arbuckle, J. G. (2011). Iowa Farm and Rural Life Poll: 2011 summary report. Ames: Iowa State University Extension and Outreach. Retrieved from https://store.extension.iastate.edu/Product/13717

Bélanger, V., Vanasse, A., Parent, D., Allard, G., \& Pellerin, D. (2015). DELTA: An integrated indicator-based selfassessment tool for the evaluation of dairy farms sustainability in Quebec, Canada. Agroecology and Sustainable Food Systems, 39(9), 1022-1046. https://dx.doi.org/10.1080/21683565.2015.1069775

Bentler, P. M. (2010). EQS (version 6.1) [Computer software]. Los Angeles: Multivariate Software, Inc.

Björnberg, $\AA$., \& Nicholson, N. (2007). The family climate scales-Development of a new measure for use in family business research. Family Business Review, 20(3), 229-246. https://dx.doi.org/10.1111/j.1741-6248.2007.00098.x

Byrne, B. M. (2006). Structural equation modeling with EQS: Basic concepts, applications, and programming (2 ${ }^{\text {nd }}$ Ed.). New York: Psychology Press.

Chase, L., \& Grubinger, V. (2014). Food, farms, and community: Exploring food systems. Durham: University of New Hampshire Press.

Creswell, J. W. (2009). Research design: Qualitative, quantitative, and mixed methods approaches (3 ${ }^{\text {rd }}$ Ed.). Los Angeles: Sage.

Davis, P., \& Stern, D. (1981). Adaptation, survival, and growth of the family business: An integrated systems perspective. Human Relations, 34(3), 207-224. https://dx.doi.org/10.1177/001872678103400303 
Dillman, D. A. (2007). Mail and internet surveys: The tailored design method (2nd Ed.). Hoboken, New Jersey: John Wiley \& Sons.

Eberle, P. R., Milliman, C. R., Peterson, W. C., \& Rendleman, C. M. (2004, August). Promotional efforts vs. economic factors as drivers of producers' decisions to expand or start a dairy. Paper presented at the American Agricultural Economics Association Annual Meeting, Denver, Colorado. Retrieved from http://econpapers.repec.org/RePEc:ags:aaea04:20140

Farrell, M. L., \& Chabot, B. F. (2012). Assessing the growth potential and economic impact of the U.S. maple syrup industry. Journal of Agriculture, Food Systems, and Community Development, 2(2), 11-27. http://dx.doi.org/10.5304/jafscd.2012.022.009

Folke, C., Carpenter, S. R., Walker, B., Scheffer, M., Chapin, T., \& Rockström, J. (2010). Resilience thinking: Integrating resilience, adaptability and transformability. Ecology and Society, 15(4), Article 20. https://dx.doi.org/10.5751/ES$\underline{03610-150420}$

Freelon, D. (2010). ReCal: Intercoder reliability calculation as a web service. International Journal of Internet Science, 5(1), 2033. http://www.ijis.net/ijis5 1/ijis5 1 freelon pre.html

Global Warming Mountaintop "Summit": Economic Impacts on New England. Hearing before the House Select Committee on Energy Independence and Global Warming, 110 th Cong. 11 (2007) (Testimony of Timothy Perkins).

Hair, J. F., Anderson, R. E., Tatham, R. L., \& Black, W. C. (1998). Multivariate data analysis (5 ${ }^{\text {th }}$ ed.). Upper Saddle River, New Jersey: Prentice Hall.

Jemison, J. M., Jr., Hall, D. M., Welcomer, S., \& Haskell, J. (2014). How to communicate with farmers about climate change: Farmers' perceptions and adaptations to increasingly variable weather patterns in Maine (USA). Journal of Agriculture, Food Systems, and Community Development, 4(4), 57-70. http://dx.doi.org/10.5304/jafscd.2014.044.001

Kuehn, D., Chase, L., Sharkey, T., \& Powers, S. (2016). Perceptions of maple producers towards climate change. Syracuse, New York: SUNY College of Environmental Science and Forestry. Retrieved from http://www.esf.edu/for/kuehn/documents/mapleproducersreportfinal 001.pdf

Lansberg, I., \& Astrachan, J. H. (1994). Influence of family relationships on succession planning and training: The importance of mediating factors. Family Business Review, 7(1), 39-59. https://dx.doi.org/10.1111/j.17416248.1994.00039.x

Leiserowitz, A., Maibach, E., Roser-Renouf, C., \& Hmielowski, J. (2012). Global warming's six Americas, March 2012 \& Nov. 2011. Yale Project on Climate Change Communication. New Haven, Connecticut: Yale University and George Mason University. Retrieved from http://climatecommunication.yale.edu/publications/global-warmings-sixamericas-in-march-2012-and-november-2011/

Miles, M. B., \& Huberman, A. M. (1994). Qualitative data analysis: An expanded sourcebook (2nd Ed.). Thousand Oaks, California: Sage.

Miller, M., Anderson, M., Francis, C. A., Kruger, C., Barford, C., Park, J., \& McCown, B. H. (2013). Critical research needs for successful food systems adaptation to climate change. Journal of Agriculture, Food Systems, and Community Development, 3(4), 161-175. https://dx.doi.org/10.5304/jafscd.2013.034.016

Nuance Communications. (2014). Dragon Dictate 4.0 [Computer software]. Burlington, Massachusetts: Nuance Communications.

Ogalleh, S. A., Vogl, C., \& Hauser, M. (2013). Reading from farmers' scripts: Local perceptions of climate variability and adaptations in Laikipia, Rift Valley, Kenya. Journal of Agriculture, Food Systems, and Community Development, 3(2), 77-94. http://dx.doi.org/10.5304/jafscd.2013.032.004

Peltier, J. W., Zhao, Y., \& Schibrowsky, J. A. (2012). Technology adoption by small businesses: An exploratory study of the interrelationships of owner and environmental factors. International Small Business Journal, 30(4), 406-431. https://dx.doi.org/10.1177/0266242610365512

Perks, H., \& Medway, D. (2012). Examining the nature of resource-based processes in new venture development through a business-duality lens: A farming sector taxonomy. International Small Business Journal, 30(2), 161-188. https://dx.doi.org/10.1177/0266242611433634

Richbell, S. M., Watts, H. D., \& Wardle, P. (2006). Owners-managers and business planning in the small firm. International Small Business Journal, 24(5), 496-514. https://dx.doi.org/10.1177/0266242606067275 
Rue, L. W., \& Ibrahim, N. A. (1998). The relationship between planning sophistication and performance in small businesses. Journal of Small Business Management, 36(4), 24-32.

Sharkey, T., Kuehn, D. M., \& Chase, L. (2015, April). Maple producers perception of climate change. In Proceedings of the 2015 Northeastern Recreation Research Symposium. Retrieved from http://scholarworks.umass.edu/nerr/2015/Papers/12/

Skinner, C. B., DeGaetano, A. T., \& Chabot, B. F. (2010). Implications of twenty-first century climate change on Northeastern United States maple syrup production: Impacts and adaptations. Climatic Change, 100(3-4), 685-702. https://dx.doi.org/10.1007/s10584-009-9685-0

Smallbone, D., Deakins, D., Battisti, M., \& Kitching, J. (2012) Small business responses to a major economic downtown: Empirical perspectives from New Zealand and the United Kingdom. International Small Business Journal, $30(7), 754$ 777. https://dx.doi.org/10.1177/0266242612448077

SPSS, Inc. (2009). PASW Statistics (version 18.0) [Computer software]. Chicago: SPSS, Inc.

Tuominen, M., Rajala, A., \& Möller, K. (2004). How does adaptability drive firm innovativeness? Journal of Business Research, 57(5), 495-506. https://dx.doi.org/10.1016/S0148-2963(02)00316-8

U.S. Department of Agriculture, National Agricultural Statistics Service [USDA NASS]. (2017). United States maple syrup production [Press release]. Retrieved from https://www.nass.usda.gov/Statistics by State/New England includes/Publications/Current News Release/201 7/2017 Maple Syrup.pdf

Walker, E., \& Brown, A. (2004). What success factors are important to small business owners? International Small Business Journal, 22(6), 577-594. https://dx.doi.org/10.1177/0266242604047411

Walker, O. C., Jr., \& Ruekert, R. W. (1987). Marketing's role in the implementation of business strategies: A critical review and conceptual framework. Journal of Marketing, 51(3), 15-33. https://dx.doi.org/10.2307/1251645

Wilmot, T. (2012). The state of the sugarbush. Farming, 15(8), 84-88. Retrieved from http://www.farmingdigital.com/aug2012\#\&pageSet=42 


\section{Appendices}

\section{Appendix A. Variable and Factor Means for Items Related to Maple Producers' Beliefs and Knowledge of Climate, Forests, and Maple Production a}

\begin{tabular}{|c|c|c|c|}
\hline Factor & Statement on questionnaire & $\begin{array}{l}\text { Statement } \\
\text { average }\end{array}$ & $\begin{array}{l}\text { Factor Mean } \\
\text { (Alpha) }\end{array}$ \\
\hline \multirow{4}{*}{$\begin{array}{l}\text { Knowledge of } \\
\text { climate } \\
\text { change }\end{array}$} & $\begin{array}{l}\text { I know a great deal about the potential impacts of climate change on } \\
\text { forests in the northeast. }\end{array}$ & 0.32 & \multirow{3}{*}{$\begin{array}{c}0.30 \\
(.927)\end{array}$} \\
\hline & $\begin{array}{l}\text { I know a great deal about the potential impacts of climate change on the } \\
\text { health and vigor of sugar maple trees. }\end{array}$ & 0.28 & \\
\hline & $\begin{array}{l}\text { I know a great deal about the potential impacts of climate change on } \\
\text { maple production. }\end{array}$ & 0.32 & \\
\hline & I know a great deal about climate change in general. ${ }^{\mathrm{b}}$ & 0.29 & -- \\
\hline \multirow{4}{*}{$\begin{array}{l}\text { Knowledge of } \\
\text { forests in the } \\
\text { northeast }\end{array}$} & $\begin{array}{l}\text { I know a great deal about forests in the northeastern United States in } \\
\text { general. }\end{array}$ & 0.34 & \multirow{3}{*}{$\begin{array}{c}0.43 \\
(.930)\end{array}$} \\
\hline & I know a great deal specifically about maple forests in the northeast. & 0.45 & \\
\hline & $\begin{array}{l}\text { I know a great deal about the factors that influence maple forest health } \\
\text { in the northeast. }\end{array}$ & 0.49 & \\
\hline & I know a great deal about the ecology of maple forests in the northeast. ${ }^{b}$ & 0.27 & - \\
\hline \multirow{3}{*}{$\begin{array}{l}\text { Beliefs } \\
\text { concerning } \\
\text { impacts on } \\
\text { production }\end{array}$} & $\begin{array}{l}\text { I believe climate change will generally increase the amount of maple sap } \\
\text { produced in the future. }\end{array}$ & -0.76 & \multirow{3}{*}{$\begin{array}{l}-0.62 \\
(.746)\end{array}$} \\
\hline & $\begin{array}{l}\text { I believe climate change will generally decrease the amount of maple } \\
\text { sap produced in the future. }\end{array}$ & $0.58^{c}$ & \\
\hline & $\begin{array}{l}\text { I believe climate change will not affect the amount of maple sap } \\
\text { produced in the future. }\end{array}$ & -0.52 & \\
\hline \multirow{3}{*}{$\begin{array}{l}\text { Beliefs } \\
\text { concerning } \\
\text { impacts on } \\
\text { business } \\
\text { operations }\end{array}$} & $\begin{array}{l}\text { I believe that maple production businesses will need to change their } \\
\text { operations in the future to adapt to climate change. }\end{array}$ & $0.75^{c}$ & \multirow{3}{*}{$\begin{array}{l}-0.70 \\
(.849)\end{array}$} \\
\hline & $\begin{array}{l}\text { I believe that maple producers will not need to make any changes to } \\
\text { adapt to climate change in the future. }\end{array}$ & -0.75 & \\
\hline & $\begin{array}{l}\text { I believe that maple production businesses will need to adopt new } \\
\text { technologies to adapt to climate change in the future. }\end{array}$ & $0.61^{c}$ & \\
\hline \multirow{4}{*}{$\begin{array}{l}\text { Beliefs } \\
\text { concerning } \\
\text { impacts on } \\
\text { maple health }\end{array}$} & $\begin{array}{l}\text { I believe climate change will influence where maple trees are able to } \\
\text { thrive in the northeast in the future. }\end{array}$ & $0.76^{c}$ & \multirow{4}{*}{$\begin{array}{l}-0.90 \\
(.826)\end{array}$} \\
\hline & $\begin{array}{l}\text { I believe climate change will make it easier for insect pests and } \\
\text { diseases to spread through forests. }\end{array}$ & $0.81^{c}$ & \\
\hline & $\begin{array}{l}\text { I believe that climate change will have no impact on the health and vigor } \\
\text { of maple trees in the future. }\end{array}$ & -0.85 & \\
\hline & $\begin{array}{l}\text { I believe that climate change will affect when tapping begins and/or } \\
\text { ends each year in the future. }\end{array}$ & $1.17^{c}$ & \\
\hline
\end{tabular}

Source: Kuehn, Chase, Sharkey, \& Powers, 2016.

a The scale used for these variable statements was: $-2=$ strongly disagree, $-1=$ disagree, $0=$ neither agree nor disagree, $1=a g r e e$, $2=$ strongly agree.

${ }^{\mathrm{b}}$ This variable was removed from the factor due to the results of the confirmatory factor analysis. Although the variable was not used to calculate the factor mean, the mean of the variable is provided.

c The item (in bold) was "reverse coded" prior to calculating the factor mean; the actual variable mean is shown (i.e., rather than the reverse-coded variable mean). The factor mean includes the item after it was reverse-coded. 


\section{Appendix B. Variable and Factor Means for Items Related to the Dependence of Maple Producers on their Business ${ }^{\text {a }}$}

\begin{tabular}{|c|c|c|c|}
\hline Factor & Item & Variable Mean & Mean (Alpha) \\
\hline \multirow{5}{*}{$\begin{array}{l}\text { Income } \\
\text { dependence }\end{array}$} & Maple production is a primary source of income for my household. & -0.37 & \multirow{4}{*}{$\begin{array}{l}-0.46 \\
(0.701)\end{array}$} \\
\hline & $\begin{array}{l}\text { Maple production provides only a small proportion of my household's } \\
\text { income. }\end{array}$ & $0.36^{c}$ & \\
\hline & My household has other sources of income besides maple production. & $1.40^{c}$ & \\
\hline & I greatly rely on maple production as a supplemental source of income. & 0.29 & \\
\hline & $\begin{array}{l}\text { I greatly rely on maple production to provide maple products for myself, } \\
\text { my family, and my friends. }\end{array}$ & 1.03 & - \\
\hline \multirow{4}{*}{$\begin{array}{l}\text { Recreational } \\
\text { dependence }\end{array}$} & $\begin{array}{l}\text { Maple production is important to me for the physical exercise it } \\
\text { provides. }\end{array}$ & 0.93 & \multirow{2}{*}{$\begin{array}{c}1.00 \\
(.872)\end{array}$} \\
\hline & Maple production is important to me because it gets me outdoors. & 1.08 & \\
\hline & Maple production is important to me more as a hobby than as work. ${ }^{b}$ & 0.21 & -- \\
\hline & $\begin{array}{l}\text { Maple production is important to me because of the enjoyment it } \\
\text { provides. }\end{array}$ & 1.41 & -- \\
\hline \multirow{5}{*}{$\begin{array}{l}\text { Social } \\
\text { dependence }\end{array}$} & $\begin{array}{l}\text { Maple production is important to me because of the social events and } \\
\text { activities it gets me involved in. }\end{array}$ & 0.14 & \multirow{4}{*}{$\begin{array}{r}0.46 \\
(.728)\end{array}$} \\
\hline & $\begin{array}{l}\text { Maple production is important because it is part of my heritage and/or } \\
\text { family traditions. }\end{array}$ & 0.87 & \\
\hline & $\begin{array}{l}\text { Maple production is important to me because it makes it possible for } \\
\text { me to spend more time with family and/or friends. }\end{array}$ & 0.52 & \\
\hline & $\begin{array}{l}\text { Maple production is important to me because it makes it possible for } \\
\text { me to meet new people (e.g., customers). }\end{array}$ & 0.33 & \\
\hline & Maple production is "in my blood." b & 1.26 & -- \\
\hline
\end{tabular}

Source: Kuehn, Chase, Sharkey, \& Powers, 2016.

a The scale used for these variable statements was: $-2=$ strongly disagree, $-1=$ disagree, $0=$ neither agree nor disagree, $1=$ agree, $2=$ strongly agree.

$\mathrm{b}$ This variable was removed from the factor due to the results of the confirmatory factor analysis. Although the variable was not used to calculate the factor mean, the mean of the variable is provided.

c The item (in bold) was "reverse coded" prior to calculating the factor mean; the actual variable mean is shown (i.e., rather than the reverse-coded variable mean). The factor mean includes the item after it was reverse-coded. 


\section{Appendix C. Variable and Factor Means for Items Related to the Connections of Maple Production Businesses with Family, Community, and Business Associations ${ }^{\text {a }}$}

\begin{tabular}{|c|c|c|c|}
\hline Factor & Item & Variable Mean & Mean (Alpha) \\
\hline \multirow{4}{*}{$\begin{array}{l}\text { Connections of } \\
\text { business with } \\
\text { family }\end{array}$} & $\begin{array}{l}\text { My family is extensively involved in the day-to-day operations of maple } \\
\text { production. }\end{array}$ & 0.36 & \multirow{3}{*}{$\begin{array}{c}0.40 \\
(.929)\end{array}$} \\
\hline & $\begin{array}{l}\text { I depend a great deal on family members to help run my maple } \\
\text { production operation. }\end{array}$ & 0.50 & \\
\hline & $\begin{array}{l}\text { The profitability of my maple production operation is greatly due to the } \\
\text { help I get from family members. }\end{array}$ & 0.35 & \\
\hline & $\begin{array}{l}\text { My family's traditions and/or heritage are greatly dependent upon } \\
\text { maple production. }\end{array}$ & 0.12 & -- \\
\hline \multirow{4}{*}{$\begin{array}{l}\text { Connections of } \\
\text { business with } \\
\text { community }\end{array}$} & $\begin{array}{l}\text { My community greatly supports my business by organizing events that } \\
\text { include and/or showcase maple producers. }\end{array}$ & -0.36 & \multirow{4}{*}{$\begin{array}{l}-0.60 \\
(.880)\end{array}$} \\
\hline & $\begin{array}{l}\text { I greatly depend on my community to create promotional materials } \\
\text { (e.g., brochures, websites) that promote my maple production } \\
\text { business. }\end{array}$ & -0.75 & \\
\hline & $\begin{array}{l}\text { I greatly depend on my community to provide me with opportunities to } \\
\text { network with other business owners (e.g., Facebook, meetings). }\end{array}$ & -0.69 & \\
\hline & $\begin{array}{l}\text { I am frequently involved in events hosted by my community (e.g., } \\
\text { farmers' markets, festivals) at which maple products are sold. }\end{array}$ & -0.54 & \\
\hline \multirow{4}{*}{$\begin{array}{l}\text { Connections of } \\
\text { business with } \\
\text { associations }\end{array}$} & $\begin{array}{l}\text { I frequently attend events and/or workshops organized by a maple } \\
\text { producers' association in my state, region, or county. }\end{array}$ & 0.45 & \multirow{4}{*}{$\begin{array}{r}0.41 \\
(.759)\end{array}$} \\
\hline & $\begin{array}{l}\text { I greatly depend on a maple producers' association to promote my } \\
\text { business. }\end{array}$ & -0.09 & \\
\hline & $\begin{array}{l}\text { I greatly depend on a maple producers' association for up-to-date } \\
\text { information about maple production. }\end{array}$ & 0.85 & \\
\hline & $\begin{array}{l}\text { I network a great deal with other maple producers, whether through } \\
\text { an association or on my own. }\end{array}$ & 0.44 & \\
\hline
\end{tabular}

Source: Kuehn, Chase, Sharkey, \& Powers, 2016.

a The scale used for these variable statements was: $-2=$ strongly disagree, $-1=$ disagree, $0=$ neither agree nor disagree, $1=a g r e e$, $2=$ strongly agree.

b This variable was removed from the factor due to the results of the confirmatory factor analysis. Although the variable was not used to calculate the factor mean, the mean of the variable is provided. 


\begin{tabular}{|c|c|c|c|}
\hline Factor & Item & Variable Mean & Mean (Alpha) \\
\hline \multirow{3}{*}{$\begin{array}{l}\text { Adaptability of } \\
\text { management }\end{array}$} & $\begin{array}{l}\text { I plan ahead for any major issues or concerns identified for the maple } \\
\text { production industry. }\end{array}$ & 0.57 & \multirow{3}{*}{$\begin{array}{r}0.81 \\
(.756)\end{array}$} \\
\hline & $\begin{array}{l}\text { My employees (if any) and I always work quickly to resolve maple } \\
\text { production problems. }\end{array}$ & 0.89 & \\
\hline & $\begin{array}{l}\text { I am always willing to make changes to my business to resolve any } \\
\text { maple production problems. }\end{array}$ & 0.98 & \\
\hline \multirow{3}{*}{$\begin{array}{l}\text { Adaptability of } \\
\text { technology }\end{array}$} & $\begin{array}{l}\text { My business has the financial resources necessary to quickly adopt } \\
\text { new maple production technologies. }\end{array}$ & 0.19 & \multirow{3}{*}{$\begin{array}{c}0.23 \\
(.864)\end{array}$} \\
\hline & $\begin{array}{l}\text { I am always able to keep my business up-to-date with new maple } \\
\text { production technologies. }\end{array}$ & 0.11 & \\
\hline & $\begin{array}{l}\text { I always invest in new technologies when I know I will get a return on } \\
\text { the investment. }\end{array}$ & 0.39 & \\
\hline \multirow{3}{*}{$\begin{array}{l}\text { Adaptability of } \\
\text { customer base }\end{array}$} & $\begin{array}{l}\text { My maple production business caters to a diverse clientele such as } \\
\text { retailers, individuals, and families. }\end{array}$ & 0.47 & \multirow{3}{*}{$\begin{array}{l}0.40 \\
(.711)\end{array}$} \\
\hline & $\begin{array}{l}\text { My customers reside in diverse locations both within and outside my } \\
\text { state. }\end{array}$ & 0.84 & \\
\hline & $\begin{array}{l}\text { My customers are attracted to the diversity of products and services } \\
\text { (e.g., tours, demonstrations) my business offers. }\end{array}$ & -0.11 & \\
\hline \multirow{3}{*}{$\begin{array}{l}\text { Adaptability of } \\
\text { the resource } \\
\text { base (i.e., sugar } \\
\text { bush resiliency) }\end{array}$} & $\begin{array}{l}\text { I have several back-up options for obtaining sap/syrup when maple } \\
\text { production is low. }\end{array}$ & -0.49 & \multirow{3}{*}{$\begin{array}{l}-0.56 \\
(.802)\end{array}$} \\
\hline & $\begin{array}{l}\text { I have several back-up strategies to keep my business running if my } \\
\text { sugar bush is damaged by storms, disease, insects, or other } \\
\text { catastrophes. }\end{array}$ & -0.55 & \\
\hline & $\begin{array}{l}\text { I can quickly adapt how and/or where I collect sap if my sugar bush is } \\
\text { damaged by storms, disease, insects, or other catastrophes. }\end{array}$ & -0.64 & \\
\hline \multirow{4}{*}{$\begin{array}{l}\text { Potential } \\
\text { adaptability of } \\
\text { business to } \\
\text { climate change }\end{array}$} & $\begin{array}{l}\text { If any changes in labor (number of workers, and/or hours worked) are } \\
\text { needed due to climate change, my business could quickly get the help } \\
\text { it needs to operate. }\end{array}$ & -0.06 & \multirow{4}{*}{$\begin{array}{l}-0.22 \\
(.797)\end{array}$} \\
\hline & $\begin{array}{l}\text { If any changes in maple production technologies are needed due to } \\
\text { climate change, my business could afford to quickly adopt the new } \\
\text { technologies. }\end{array}$ & -0.08 & \\
\hline & $\begin{array}{l}\text { If any changes in customer base are needed due to climate change, my } \\
\text { business could quickly find and attract new customers. }\end{array}$ & -0.24 & \\
\hline & $\begin{array}{l}\text { If any severe damage to my sugar bush occurred due to climate } \\
\text { change, my business could quickly change how it collects and/or } \\
\text { obtains sap. }\end{array}$ & -0.49 & \\
\hline
\end{tabular}

Source: Kuehn, Chase, Sharkey, \& Powers, 2016.

a The scale used for these variable statements was: $-2=$ strongly disagree, $-1=$ disagree, $0=$ neither agree nor disagree, $1=a g r e e$, $2=$ strongly agree. 